\title{
An Assessment of Visitor Expenditure Methods and Models
}

\author{
Douglas C. FrechtLing
}

\begin{abstract}
There has been a great deal of research devoted to estimating visitor expenditures in countries, regions, cities, and other areas as related to specific events. Such estimates are essential for producing comprehensive estimates of tourism's economic benefits in an area. This review of methods used to estimate visitor expenditures applies definitions of relevant concepts developed by the World Tourism Organization (WTO) to promote standardization and quality in tourism statistics. Three contexts are identified for visitor-expenditure studies: occasion, venue, and time frame. Occasion recognizes the visitor-expenditure studies that have focused on annual visitor expenditures in a study area in contrast to those focusing on visitor expenditures associated with a given event. The latter occasion raises a number of issues regarding what constituted qualified visitors and qualified expenditures. Relevance, coverage, and accuracy principles are applied from the literature to assess 11 methods and models. Guidance is provided for selecting valid approaches by occasion.
\end{abstract}

Keywords: tourism impact; economic impact; tourism expenditures; visitor consumption; tourism expenditure models

Serious research on the economic benefits of tourism has a long history. Mathieson and Wall (1982) note studies dating back to 1933 (Ogilvie) and 1953 (Alexander) addressing this topic. They concluded that most studies up to the early 1980s focused on the economic benefits to destination areas, a finding that Sheldon (1990) reiterated. Subsequently, numerous articles have been published addressing the economic benefits from visitors to specific events at destinations (e.g., Kasimati 2003; Daniels, Norman, and Henry 2004; Brown, Var, and Lee 2002; Crompton, Lee, and Shuster 2001; Tyrrell and Johnston 2001; Getz 1994; Long and Perdue 1990).

Measurement of the economic benefits along with related costs of tourism can help marketers, planners, and others with an interest in visitor activities to reach a variety of objectives:

- It informs public officials and business managers of the benefits to a community of investing in tourism promotion and in the development of tourism facilities and sponsorship of events (Crompton, Lee, and Shuster 2001);

- It assists tourism marketers in evaluating the effectiveness of their efforts and the effects of additional facilities on demand for current ones;
- It helps educate tourism-related employees about their role in economic and business development and how their labor contributes to the economic health of their communities;

- Through expressing the returns to promotional and facility investment, it can encourage both business and government to seek out cooperative partnerships for mutual benefit;

- By demonstrating the effects of tourism development to the general public, it helps citizens rationally choose whether to encourage or resist additional tourism marketing or development;

- It aids public officials in developing laws and policies that best promote the economic, social, and cultural health of their citizens and avoiding decisions that would threaten this health.

In short, developing techniques to measure the economic benefits and costs of tourism activities assists residents, consumers, businesses, and governments in making efficient and effective marketing and development decisions.

A number of methods and models have been proposed to measure or estimate the economic benefits of visitors (e.g., Frechtling 1994b), and the vast majority begin with the estimation of the expenditures these visitors make at an event site or in a defined geographic area (Vanhove 2005; Tyrrell and Johnston 2001; Vaughan, Farr, and Slee 2000; Frechtling 1994a). Mihalic (2002) argues for the centrality of visitor expenditures in tourism economic-impact measurement quite cogently:

Tourism is an expenditure-driven economic activity. That is, the consumption of tourism is at the centre of the economic measurement of tourism and the foundation of the economic impacts of tourism and,

Douglas C. Frechtling is a professor of tourism studies in George Washington University's School of Business. He specializes in teaching in the Sustainable Destination Management faculty of the university's Master of Tourism Administration degree program, the oldest such program in the Americas. This article is part of a larger research program investigating the advantages and limitations of various approaches to estimating the economic costs and benefits of visitors to a geographic area in the university's International Institute of Tourism Studies.

Journal of Travel Research, Vol. XX, Month Year. Page 1-10

DOI: $10.1177 / 0047287506288877$

(C) 2006 Sage Publications 
therefore, understanding tourism consumption is essential for understanding tourism's economic impacts. (p. 88)

This article examines a number of methods that have been proposed and applied to estimate visitor expenditures in such a geographic area. The methods are grouped into seven main categories, and the methodologies are summarized and evaluated. Finally, recommendations for choosing among these methods are presented.

The scope of this examination excludes estimating the direct impacts of these expenditures on other measures of benefits to the defined area, such as business receipts, profits, employment, personal income, and government revenue. It also excludes consideration of the so-called secondary or multiplier impacts of visitor expenditures (e.g., see Tribe 2005; Vanhove 2005; Dwyer, Forsyth, and Spurr 2004). These techniques are essential elements to successfully measuring the full range of visitor benefits but cannot be adequately covered in this space.

This article also is devoted to the economic benefits of visitors, not to the negative impacts or costs to a community. These outcomes also have been addressed in the academic literature (e.g., Vanhove 2005; Bull 1995; Frechtling 1994a). The restricted scope of this article does not signify the author's view that the direct benefits, secondary impacts, or the costs of visitor activities in an area are inconsequential but rather that these topics deserve full-scale treatments in articles of their own.

This current treatment is informed by the WTO's work on encouraging adoption of standard terminology and methodologies for the collection and analysis of tourism statistics by national and other governments (World Tourism Organization 2005b). For this article, the term visitor expenditure follows the WTO's definition of visitor consumption:

Visitor consumption is the basic concept measuring tourism activity and refers to total consumption of or on behalf of visitors and could, consequently, also be termed as "visitor demand."

In visitor consumption concepts, visitor final consumption expenditure in cash (its main component), corresponds to the term "visitor expenditure," traditionally used in the analysis of tourism.

Visitor consumption exceeds visitor purchases on a trip. It encompasses these purchases as well as all expenditure on goods and services by all other institutional units on behalf of visitors. If cash or financial assets are transferred to the visitor to finance his/her trip, the purchases funded by these are included in visitor consumption. Along with this are all forms of transfers in kind and other transactions benefiting visitors where it is not cash or financial assets which is provided to the visitors but the goods and services themselves - thus the consumption of individual nonmarket services is included. Essentially all transactions where there is a direct link between the visitor and the producer/provider of the good or service are within scope. (World Tourism Organization 2005a)

Note that this definition expands the concept from purchase to consumption-the acquisition of consumption goods or services for final use by the visitor regardless of whether the visitor (or others in his household) has financed the expenditure or not (Commission of the European Communities et al. 1993). For example, a business visitor may not purchase a night's stay in a hotel (if his employer has booked and paid for it) but still consumes it, and this impact should be included in measuring his expenditures at the destination. A practical issue arising from the WTO definition is whether a visitor-expenditure study actually addresses "expenditure on goods and services by all other institutional units [e.g., other households, a business unit, a government agency] on behalf of visitors." For example, if the visitor-survey method is used to estimate visitor expenditures and it asks respondents to recount what they spent while in the area, this would exclude purchases on their behalf (by employers, hosts, clients, etc.) while they are visiting. Manente and Minghetti (1998) are alone among articles reviewed for this present article in recognizing this requirement. This suggests that the economic impact of visitors in study areas has been underestimated consistently in past studies.

Similarly, visitor in this article follows the WTO's definition as "any person travelling to a place other than that of his/her usual environment for less than 12 months and whose main purpose of visit is other than the exercise of an activity remunerated from within the place visited" (WTO 2005a).

Tourism is primarily a spatial phenomenon, so geographic considerations are essential. Visitor-expenditure research acknowledges a study area: the defined geographic locale within which the visitor expenditures of interest take place.

The wealth of studies publicly available on measuring visitor expenditures reference three contexts:

1. Occasion: a specific event or a significant time period (usually one calendar year)

2. Venue: a specific site or geographic area

3. Time frame: past or future

\section{Occasion}

There are somewhat different challenges when estimating annual visitor expenditures for a study area such as a country, province, city, or village than when estimating these expenditures for a given event at a more restricted site that attracts visitors. This article adopts Getz's (1994, p. 4) definition of an event with a particular relationship to tourism, accepted by Ryan (1998, p. 340), as a "one-time or infrequently occurring event outside the normal programme or activities of the sponsoring or organizing body." The category includes fairs, festivals, sports games, exhibitions, performances, conferences, and trade shows that attract visitors to the destination.

Research on tourism's annual economic benefits to a study area usually require that all days of the year be represented by these expenditures, rather than just the duration of the event. This requires at least a probability sample of qualified expenditures on all days of the year. In contrast, measuring expenditures related to an event is bounded by the dates of the event, perhaps with extensions of several days before and several days after to cover all associated visitor spending.

The event may be gated as well as limited in time, making identification of visitors rather straightforward. 
Except for islands, destinations are not gated, and ensuring that the expenditures of all visitors are represented is quite problematic, as valid sampling frames are difficult to define. On the other hand, events are frequently one off, and if the method used to estimate visitor spending is not applied properly, there is no opportunity to rectify the failure.

Tourism economic-impact sources are unanimous that qualified visitor expenditures must comprise consumption at the site or within the study area "that would not have occurred without tourism" (Sheldon 1990, p. 29, quoting Baretje 1982). When a study focuses on events that attract visitors and on their specific impact, the issue becomes more complex. Vanhove refers to the "with and without principle" (2005, pp. 204, 228): the difference an event or project makes in the study area's economy. Crompton, Lee, and Shuster (2001, p. 81) clearly state the widespread view: "Economic impact attributable to [an event] relates only to new money injected into the [study area] economy by visitors... from outside the community... Expenditures by those who reside in [the study area] represent only a recycling of money that already exists there" (see also Tyrrell and Johnston 2001). We can call this the relevance principle of sound visitor-expenditure estimation: only those injections of new money attributable to the destination or the event should be measured as visitor expenditures (Frechtling 1994a; Fleming and Toepper 1990; Getz 1994)

But visitors from outside the community raises another set of issues: are all persons entering the study area who reside outside the area qualified as visitors? Researchers on tourism expenditures have identified a number of categories of travelers in an area who should be considered visitors and whose expenditures should be incorporated in an estimate of visitor expenditures:

1. Visitors in the standard, WTO sense of persons who reside in an area outside the study area and make a short-term visit, sometimes to participate in an event, and then return home.

2. Nonresident producers of an event (Gazel and Schwer 1997)

3. Nonresident sponsors of an event (Turco 1994)

4. Nonresident media representatives covering an event (Turco 1994)

5. Nonresident exhibitors at a trade show and other vendors at an event (International Institute of Tourism Studies 2005; Turco 1994)

6. Operating crew of public transportation conveying visitors to the area (e.g., flight attendants and pilots; Braun, Xander, and White 2002)

7. Future visitors (Gazel and Schwer 1997)

Nonresident here is used in the sense of individuals with permanent residences outside of the study area. The first five categories above seem valid candidates for inclusion in a study of visitor expenditures related to a destination study area or an event in a study area. Inclusion of all of them would satisfy a coverage principle: including all expenditures in the study area that would not have occurred in the absence of a visit to the study area or to a tourism event (Getz 1994; Fleming and Toepper 1990; Frechtling 1994a ).

Public transportation crews (Item 6) are problematic in that they function as commuters, according to the United
States Department of Transportation definition: "a person who travels regularly between home and work or school" (United States Department of Transportation 2005a). This suggests they should be excluded from visitor-expenditure studies that strictly observe the WTO definitions. The impact of their spending could be picked up in measures of the induced impact of visitor spending in a multiplier analysis.

Future visitors, defined as event visitors who reported they would visit the study area again within 1 year as a result of their visit to attend the event, has been proposed as a legitimate visitor-expenditure category, but apparently, not actually included in the event-expenditure estimates (Gazel and Schwer 1997). However, this virtual-visitor spending should not be included in a visitor-expenditure study because there is no way to estimate the amount of such spending reasonably, and it does not take place within the time period surrounding the event.

In their study of the impact of a Grateful Dead (GD) concert on the Las Vegas economy, Gazel and Schwer (1997) include the expenditures of "residents who attended the show [and] reported that they would travel someplace else to patronize GD concerts in the absence of the show locally" (p. 49). Ryan (1998, p. 345) terms this phenomenon "retained expenditure." This clearly is excluded from visitor expenditures by the above definition but arguably might contribute to the economic impact of an event on a local area. Moreover, it raises the troubling question of why resident spending, fundamentally excluded from tourism-event expenditure measurement, should be included in this case (Getz 1994). Moreover, such resident travel to outside destinations is part of the leakages that condition an economy's secondary impact or multiplier process (Tribe 2005; Vanhove 2005). To include them in direct-impact measurement as well is a form of double counting.

When estimating the visitor expenditures associated with an event, some researchers have advocated excluding the following categories of visitors and their spending because such expenditures in the study area are not attributable to the event and likely would have occurred without it (violating the relevance principle):

1. Casuals, defined as visitors already in the study area for other reasons and who attend the event instead of doing something else (Crompton, Lee, and Shuster 2001; Tyrrell and Johnston 2001)

2. Time Switchers, defined as visitors who had been planning to visit the study area but changed the timing of their visit to attend the event (Crompton, Lee, and Shuster 2001; Ryan 1998; Getz 1994)

Excluding casuals observes the relevance principle by limiting visitor expenditures to those related to the event. Visitors already in the area for other reasons are not injecting new money when they visit the event.

However, identifying and excluding time switchers is quite problematic. For example, the questionnaire used by Crompton, Lee, and Shuster (2001) to assess spending related to the Springfest 1999 festival in Ocean City, Maryland, included the question, "Would you have come to the Ocean City area in the next three months if you had not come at this time for this event?" (p. 83). If a respondent answered "Yes," then his or her spending was excluded as 
time switching. However, the Ocean City area includes several thousand housing units of the second- or vacationhome variety. Visitors from other areas regularly spend the weekend or longer at these second homes, but they may visit the town of Ocean City and spend money there only because of Springfest (this author is one of these visitors). Plans to visit the Ocean City area at some other time should not affect the eligibility of these expenditures; they all are attributable to the event.

Moreover, to classify visitors as time switchers, we are asking visitors at an event to speculate on what they would have done in the absence of the event. Unless travel plans are equivalent to visits, they might not have visited the area at all in the absence of the event. This holds true for event producers, sponsors, media, and exhibitors as well. Members of each of these groups may have planned to visit the area in the absence of the event, but their expenditure presence is real, whereas their possible visit at another time is speculative. This suggests there is no principle served by trying to identify time switchers.

To further complicate this estimation, researchers have suggested that these exclusions be relaxed if time switchers or casuals extend their length of stay because of the event (Crompton, Lee, and Shuster 2001). This requires additional questions posed to respondents that may give rise to lower response rates or inaccurate replies.

Getz (1994) and Vanhove (2005) argue that crowdingout effects occur when traditional visitors, that is, usual or normal visitors to the study area, avoid it during an event's duration by either visiting another region instead or visiting the study area at another time. If the former can be shown to occur during an event, the amount lost should be subtracted from the estimate of visitor spending according to this view. Crompton (1999, p. 33) calls this "displacement cost" and notes a study estimating that $\$ 165$ million of visitor expenditures did not occur in the area during the 1984 Los Angeles Olympic Games that would have occurred without the Games.

It is not obvious how to validly estimate this virtual spending (or nonspending). Getz (1994) maintains, "this can only be assessed by surveys of businesses, but with the caution that the perception of managers is not a particularly reliable source." Attempting to measure visitor spending that did not occur in an area does not seem a worthy use of resources and should be abandoned in the name of the accuracy principle: use valid and reliable measurement methods where methodologies satisfy validity criteria (i.e., measuring only what we intend to measure; Alreck and Settle 1995) or results satisfy reliability criteria (i.e., same measures from repeated applications of the same method; ibid.). This criterion was recommended by Fleming and Toepper (1990) and affirmed by Frechtling (1994a).

Turco (1994, p. 28) favors reducing "direct expenditures ... that arise as a result of the operation of the sporting event" by the receipts of nonresident vendors at the event. He argues that this money "left the local economy with the ... nonresident businesses when they returned home" (ibid., p. 31). This position also is adopted by Chhabra, Sills, and Cubbage (2003). This exclusion might be valid if one were estimating local business receipts attributable to an event but should not be followed in measuring visitor expenditures, as the nature of the recipient of these expenditures is not part of the definition.
To exclude them from visitor expenditures would violate the coverage principle.

\section{Venue}

As noted above, visitor expenditures at destinations typically are measured in relation to two types of areas: significant geographic areas (e.g., countries, regions, provinces, urban areas, towns) and sites where events occur that draw visitors.

Daniels, Norman, and Henry note that measuring visitor economic impact is facilitated if care is taken to define the study area "to include enough area to include the most important aspects of the impact, and yet not too much area or the effects will be masked by extraneous economic activity" (2004, p. 184). But the researcher is not limited to a single administrative area. For example, Vaughan, Farr, and Slee produced separate visitor-expenditure estimates for a local administrative area and a larger economy (2000), and Tyrrell and Johnston (2001) produced estimates of expenditures by location of purchases for a festival in Newport and the state of Rhode Island, where the city is located.

\section{Time Frame}

Extant visitor-expenditure studies have covered two distinct time periods. Most relate to the past: a particular year in an area or the time period when an event took place. However, studies also have been published that project future visitor spending from a major event proposed to be held (Madden 2002; Brown, Var, and Lee 2002) or visitor expenditures in a study area (Frechtling 2001). Forecasting methods are used to project the number of visitors expected to attend the event and their average daily expenditures (Madden 2002). Many of these are designed to gain government support and are not followed up with ex post studies (Kasimati 2003), or the ex post studies find "the effect of these events on host communities is either insignificant or an order of magnitude below the figures espoused by promoters" (Matheson 2002, p. 2). This article addresses the past time frame only.

\section{Alternative Expenditure Estimation Methods}

The WTO (2000, pp. 41, 55-56) has noted the following estimation methods available to estimate visitor spending:

1. Existing data

2. Household surveys

3. Visitor surveys

4. Tourism establishment surveys

5. Central bank data

6. Expenditure models

a. Expenditure ratio model

b. Cost factor model

Based on a review of literature at the time, Frechtling (1994a, p. 368) noted four other methods:

6. Expenditure models c. Seasonal-difference model d. Supply-side judgmental model

7. Direct observation 


\section{EXISTING DATA}

As WTO (2000, p. 43) cautions, "Before undertaking any new collection of visitor expenditure data, it is essential to check whether the required data, or similar data, are available." At the national level, this is an important step. Intercity public-transportation modes, for example, carry only visitors as passengers, and their transport spending is available from administrative reports. However, visitorexpenditure data relating to a subnational study area or any single event must have been collected by some purposeful method; these data do not generate themselves. Following is an enumeration of these methods that this author intends to be exhaustive.

\section{HOUSEHOLD SURVEYS}

"The World Tourism Organization (WTO) considers the Household Income/Expenditure Survey (HI/ES) to be the most efficient and suitable instrument for measuring domestic tourism activity" (World Tourism Organization 2005c, p. 1). Many countries have systems in place that continually survey probability samples of their households on consumption expenditures, personal income, employment and labor-force participation, and consumer preferences (World Tourism Organization 2005c). It is relatively straightforward to ask respondents to distinguish local purchases from those made on qualified trips out of the usual environment. In some cases, household surveys devoted entirely to gathering tourism activity and expenditure information have been conducted (Vanhove 2005; Kim, Spotts, and Holecek 1998).

The strengths and weaknesses of this approach for measuring visitor expenditures have been catalogued (WTO 2000; Frechtling 1994a). A major threat to validity for this approach is recall bias, or memory effects. These are terms applied to the phenomenon of household-survey respondents underreporting long-distance travel activities when asked 1 month to 1 year after the trip. Moreover, this underreporting tends to vary directly with the elapsed time between the trip and the survey. Such bias has been documented in surveys of tourism spending (Mak, Moncur, and Yonamine 1977; Bureau of the Census 1979; Chau 1988; Stynes and Mahoney 1989; Burd 1991; Rylander, Propst, and McMurtry 1995; Lian and Denstadli 2003).

The time elapsed between travel activity and its reporting in a household survey also affects recall of trips. A number of researchers have found the number of eligible trips reported declines with the length of the recall period (Meyberg and Brog 1981; Madre and Maffre 2001; Lian and Denstadli 2003). The American Travel Survey conducted by the United States government in 1995 asked respondents to recall trips taken in each of the 3 months prior to the interview. Analysis of the results indicated that consistently more trips were reported for a given month when the recall period was 1 month than when it was 2 or 3 months (Bureau of Transportation Statistics 1997). Armoogum and Madre (2003) found in an investigation of the French National Personal Transportation Survey, "People appear to forget their business trips more often than their short private trips and the latter more than their long private trips" (p. 165).
Of course, recall bias formally applies only to cases where the respondent had knowledge of an activity but memory lapse prevents him from accurately reporting it. But this particular cause of nonresponse is not always the problem. Youssefzadeh (2003, p. 40) points out, "Although it would be interesting to know the allocation of costs between the employer and the traveler for business travel, experience with tourism surveys has shown that often respondents simply do not know the answer as the costs of their travel are not always transparent to them." Whatever the reason, a number of researchers have noted that respondents cannot recall expenditures accurately after the fact (Youssefzadeh 2003; Frechtling 1994a). The evidence supports the conclusion that household surveys do not satisfy the accuracy principle for either area or event visitorexpenditure data.

A recurring problem in surveys of visitor spending, whether of households or visitors onsite, is presented by package tours, which provide a combination of transportation, accommodations, meals, and entertainment for a single price and may involve visits to several destinations. Purchasers usually cannot discern how much of the tour price is attributable to individual items consumed in a given area. Consequently, they cannot give the interviewer reliable information on the distribution of their expenditures (e.g., accommodations, meals, admission fees, local transport) in an area under study. The World Tourism Organization (2000) suggests using surveys of tour operators to indicate spending on the components of package tours (accommodations, local transport, meals, etc.) to allocate visitor reports of total packagetour spending.

\section{VISITOR SURVEYS}

Smith (2000, p. 225) has noted that "most economic impact measures of tourism are ad hoc indicators based only on visitor survey data." Optimally, this involves a survey of a probability sample of visitors while in the study area. The results from questions on expenditures can produce estimates of mean visitor expenditure per person per day, and then multiplying this by the number of qualified visitors produces the estimate of visitor spending (Crompton, Lee, and Shuster 2001). Estimation of this mean expenditure is not straightforward, because some visitor expenditures, such as lodging per night and taxicab transportation, may vary little by party size up to three. Crompton, Lee, and Shuster (2001) suggest asking onsite respondents how many people are in the immediate visitor group, defined as the number of people for whom you typically pay the bills, that is, your family or close friends.

Surveys of travelers can be conducted as they enter an area (entry surveys), as they leave the area (exit surveys), or while in the area under study (on-site surveys); (Chhabra, Sills, and Cubbage 2003; Daniels, Norman, and Henry 2004; Crompton, Lee, and Shuster 2001). In addition, en route surveys can be conducted while passengers are traveling on an airplane, train, bus, or ship to or from the destination (Office of Travel and Tourism Industries 2004; UK International Passenger Survey cited in Vanhove 2005), or even after visitors return home (Daniels, Norman, and Henry 2004). Among these, entry surveys and en route surveys of 
arriving passengers are the least satisfactory because they cannot obtain information on actual expenditures in the area, only amounts intended, or budgeted, to be spent.

Interview methods include personal interviews and selfadministered questionnaires (handed to visitors selected for the sample and retrieved after they have been completed). The latter may include a diary that the visitor is expected to fill out as she makes qualified expenditures.

Selecting a probability sample of visitors at a destination is not a trivial task, even through it alone among sampling techniques provides reliable and valid samples of the visitor population of interest (Vanhove 2005). Getz (1994, p. 445) maintains that "none of the nonrandom methods can be used for estimating the characteristics of the whole crowd, at least according to strict statistical practices," ruling out quota and other convenience sampling techniques. Fleming and Toepper (1990) argue that a large sample cannot make up for a flawed sampling design. Crompton (1999) provides advice on sampling techniques at events. Estimating visitor volumes at ungated events is most challenging but is crucial to obtaining reliable estimates of associated visitor spending.

The evidence suggests that the exit-survey model can provide the most accurate visitor-expenditure information if expenditure recall is limited to the previous 24-hour period and multiplied by the projected length of stay (Vaughan, Farr, and Slee 2000; Frechtling 1994a; Haynes 1975).

\section{TOURISM ESTABLISHMENT SURVEYS}

The sellers of air, bus, rail, and cruise transportation can estimate sales to travelers with a high degree of reliability because of the nature of their customers. However, it is unlikely that restaurateurs, gas station operators, or sports or entertainment facility managers can distinguish receipts from visitors versus residents (Mules 1999; Frechtling 1994a; Fleming and Toepper 1990). Sheldon (1990) notes that this method is problematic because establishment receipts may include local spending, may not include all establishments where visitors spend money, and cannot provide any depth on the number of visitors, length of stay, or origin. Another problem with this method is that managers of visitor-serving businesses may be reluctant to share data on their operations for fear of its ending up in competitors' hands (Carlsen 1995; Vaughan, Farr, and Slee 2000).

\section{CENTRAL BANK DATA}

Sheldon (1993, p. 13) observed that "bank records of foreign exchange transactions" are one of "the three most commonly used methods of tourist expenditure data collection." A number of countries measure foreign-visitor expenditures within their borders through accounting for foreign-exchange purchases by these visitors. The country's central bank attempts to compute the amount of national currency sold to visitors each period through reports from agencies making such currency sales.

The validity of this method depends on the system's being able to (WTO 2000):
1. distinguish foreign transactions generated by international visitors from all other transactions (relevance principle);

2. include all transactions undertaken by international visitors (coverage principle);

3. ensure that the transactions are recorded, identified, and transmitted accurately to the central bank (accuracy principle).

The WTO (2000) provides nine conditions that threaten the validity of central-bank estimates of international-visitor spending. Moreover, the central-bank method only can suggest total foreign-visitor spending at the national level but not categories of this spending or any domestic spending. This prevents its use in measuring visitor spending in subnational areas or associated with individual events. Moreover, the method is being abandoned in Europe for other reasons. The European Union noted that this was the preferred method for estimating the travel account in national balance of payments accounts in 11 European nations (Ortolani 2000). These nations took part in the European Monetary Union (EMU) shift to a single euro currency in 2001. After this, they were not able to track international travel receipts and expenditures from other countries within the EMU, requiring a change to the sample-survey method.

In summary, the bank-return method fails the coverage, relevance, and accuracy principles in relation to estimating visitor expenditures at subnational areas and individual events.

\section{EXPENDITURE MODELS}

These models attempt to capture the salient aspects of visitor expenditures without actually surveying visitors about this activity. They differ in the amount of information they require from visitors and their internal logic.

\section{Expenditure Ratio Model}

These expenditure models rest on a foundation of certain expenditure-related data that are readily available and relatively sound. To this is added a superstructure of travelexpenditure relationships that build up to a total of all travel spending in an area (Rovelstad 1994; West Virginia University 1981).

The simplest version of this approach comprises four steps. The first step is to gather data on hotel and motel room receipts in an area, such as a county or metropolitan area. These often can be obtained from state or local tax agencies, particularly if the jurisdiction imposes a special sales tax on these receipts. The second step is to conduct a survey among visitors to the area to obtain estimates of the total amount spent in the area and expenditures on lodging at hotels and motels, specifically. In the third step, the ratio is computed of total visitor spending from the survey to the survey estimate of spending on hotel and motel room rental. Finally, the fourth step is to multiply this ratio by the hotel and motel room receipts gathered in step one, and the product is a measure of total spending by visitors in the area.

The leverage associated with this approach can be quite high. For example, the Travel Industry Association of America estimates of traveler spending in Maryland for 2002 suggests 
total traveler spending is 7.32 times hotel and motel room receipts in the state. This indicates that every dollar of estimated spending on hotel/motel rooms translates into $\$ 7.32$ of total traveler spending in the state. Should the estimated ratio of total spending to these receipts erroneously be 5\% too high (say, from overreporting by respondents), this would add $\$ 450$ million in unwarranted expenditures to the state estimate.

The validity and estimation accuracy of this approach for local areas is improved if the following criteria are satisfied:

1. The survey sample is large enough to produce relatively accurate estimates of the total-expenditure-to-lodgingreceipts ratio for individual areas (accuracy principle).

2. Survey procedures follow best practices in samplesurvey conduct, and the response rate exceeds $70 \%$ to $80 \%$ (accuracy principle).

3. Survey-respondent recall bias does not distort this ratio (accuracy principle).

4. Surveys are conducted annually rather than assuming the ratio remains stable over several years (accuracy principle).

5. The hotel and motel room receipts data are accurate for a particular year and not distorted by payment of past taxes and penalties for previous periods or underreporting (accuracy principle).

6. Survey respondents only report what they spent in the area, rather than total trip expenditures or spending in other areas (relevance principle).

This method is not able to distinguish visitor expenditures related to a given event in a study area, thus violating the coverage principle.

\section{Cost-Factor Model}

The cost-factor model for estimating travel expenditures has a history dating back at least 35 years (Church 1969; Frechtling 1974). The most prominent example is the Travel Industry Association of America's (TIA) Travel Economic Impact Model (TEIM; Travel Industry Association of America 2004, p. 88). In this model, travel expenditures are estimated for 19 different items in six basic expenditure categories: public transportation, auto transportation, lodging, food, entertainment and recreation, and incidental purchases.

The expenditure component of the TEIM comprises a set of equations for each state in which the independent variables are the volumes of various travel activities (e.g., miles traveled by automobile, nights spent in hotels), the coefficients are the costs per unit of each activity (called per-unit cost factors), and the dependent variables are travel expenditures for certain categories of travel-related goods and services (expenditure items). Estimates of the activity volumes are derived from TIA's monthly travel survey, whereas the per-unit cost factors are obtained from respected industry and government sources.

The model allocates travel expenditures among areas by simulating where the exchange of money for goods or services actually took place. According to their nature, some travel expenditures are assumed to occur at the traveler's origin, some at his destination, and some en route.

This cost-factor model appears to have produced acceptable estimates of United States resident-visitor spending in individual states and counties annually since 1987 (Travel Industry Association of America 2004). However, it cannot be used to produce visitor expenditures for individual events, violating the coverage principle for that occasion.

\section{Seasonal-Difference Model}

Another proposed expenditure-estimation method requires examining the monthly distribution of the receipts of a type of travel-related business (e. g., hotels and motels, eating and drinking places, amusement and recreation services) during a year's time to determine the month with the lowest total (Sanders et al. 1993). This monthly total is assumed to represent average monthly sales to local residents in the absence of any visitors. This amount is subtracted from the totals for each of the 11 other months in the year, and the residual is visitor spending.

This method has not gained acceptance in the literature on visitor-expenditure studies, perhaps because of its structural flaws. It tends to underestimate tourist spending to the extent that the low-month receipts include some traveler spending. A summer resort area's hotel and motel receipts in February (lowest monthly total), for example, surely include the spending of some business travelers. When these receipts are subtracted from other months, this spending is not accounted for.

This method tends to overestimate traveler spending to the extent that receipts in the peak months are inflated by nonvisitor purchases. For example, amusement- and recreationservice receipts are higher in the summer in many areas because local residents spend more time outdoors then or take vacations at home. Sales of restaurants and other establishments may be higher in July than February because of nontourist, weather-related business activity, such as construction or water-freight transportation. Building and highway construction employment soars in the summer in many climes, and this would provide a boost to restaurant sales that is not tourism related. Consequently, the method violates the relevance principle.

The method also ignores the impact of trend on the monthly distribution of receipts. If the local economy is growing through time, then July sales of many businesses will be somewhat higher than February's because of trend growth in local activity rather than of tourism. Finally, conceptually, the method only works in an area with a clearly defined tourist season. The theory cannot apply in areas that have high seasons in both summer and winter, such as major United States ski resort areas.

\section{Supply-Side Judgmental Model}

The British Columbia Ministry of Development, Trade, and Tourism (Cavanagh, MacDougall, and Burd 1992) proposed an input-output model specifically designed to display tourism's contributions to the province. It embodies three steps to determine the economic impact of the tourism industry: (1) identify the types of businesses composing the tourism industry; (2) measure the output, GDP, and other measures of economic impact of these businesses; and (3) estimate the proportion of these measures that can be attributed to tourism expenditures for each business type.

The first two steps are straightforward and follow commonly accepted principles of definition and input-output 
model data collection. The third step, however, relies on the judgment of experts. Apparently, such a panel has developed a set of ratios of business revenues attributable to tourists to total revenues for each type of business. These tourism ratios then are applied to the supply-side measures of revenues to derive estimates of visitor spending in an area. A similar approach was recommended at the national level in Canada "to measure the overall contribution of tourism to the rest of the economy" (National Task Force on Tourism Data 1989, p. 18).

This adds a large element of subjectivity to what is basically an objective accounting process. It is impossible to assess the accuracy of these estimates at the national level. If this were possible, the actual tourism ratios would be used rather than the judgmental ones. Moreover, a different panel of experts might arrive at significantly different ratios. How these would change through time to reflect industry reality is a mystery. And the model cannot estimate visitor expenditures related to a specific event. Consequently, this method violates the relevance and accuracy principles of sound visitorexpenditure estimation.

\section{DIRECT OBSERVATION}

A simple way to obtain estimates of visitor expenditures appears to be actually to observe the visitor purchasing food, gasoline, lodging, and other items by following him around and recording purchases. Participant observation has been used in analyzing visitor behavior. Getz, O'Neill, and Carlsen (2001) used trained observers to identify service failures and crowd reaction to a sporting event. Bowen (2002) served as a single-participant observer on a soft adventure inclusive tour to record and analyze satisfaction with the experience among fellow travelers. Davis and Morais (2004) used participant observation to map tourist flows around a small town. Seaton (1997) used "unobtrusive, participant observation" (p. 27) at an 8-day arts festival to gauge audience motivations, satisfactions, reactions to event organization, and audience profiles to help offset problems with a visitor survey. None of these researchers extended their observations to visitor spending.

While there is no definitive answer in the research reviewed for this article, it appears that participant observation has not been extended to estimating visitor expenditures because this would be too obtrusive and possibly might change visitor patterns, even if those observed permitted it (Ritchie 1975).

\section{CONCLUSION AND SELECTION RECOMMENDATIONS}

This review of the extensive research literature on estimation of visitor expenditures during the past 30 years distinguished seven methods used to develop these estimates. Applying the WTO conceptual definitions and requirements and three principles (relevance, coverage, and accuracy principles) deemed helpful in establishing measurement validity indicates which methods are likely to provide the most valid measures.
The most important distinction in assessing these methods is occasion, recognizing two types: (1) annual estimates of visitor expenditures in some study area and (2) estimates of visitor expenditures generated by a specific event.

Estimating the expenditures of qualified-study-area visitors is relatively straightforward and requires the researcher to apply only three criteria to be assured that a given expenditure qualifies as a visitor expenditure:

1. The visitor permanently resides outside the study area;

2. The visitor purchases or consumes products provided within the study area while visiting;

3. The visitor purchases or consumes products provided within the study area during the study period.

If an expenditure meets these three criteria, it is a qualified visitor expenditure in the study area during the study period.

Among the estimation methods examined that apply to estimating annual visitor spending in specific areas, visitor surveys and cost-factor models, designed and applied according to commonly accepted principles of sound research, will produce estimates that satisfy the relevance, coverage, and accuracy principles. Transparency should be the essence of the research communication. All elements of the survey or all equations and sources of the model data must be presented for reader evaluation. (For an example of survey transparency, see United States Department of Transportation 2005b, describing the 1995 American Travel Survey).

Getz (1994) aptly summarizes the importance of surveys in event-impact studies: "Because of the uniqueness of special events, there is generally no viable substitute for visitor surveys. Surveys are required to determine the proportion and number of tourists and their trip motivations, activity, and spending patterns" (pp. 444-45).

Among the methods and models found and examined for this occasion, only visitor surveys pass the relevance, coverage, and accuracy tests. These surveys should focus on interviewing visitors as they leave the venue, distinguish those who attend the event on a trip for that purpose (avoiding casuals), ask about spending during the previous 24 hours, and follow best practices in survey design and conduct. These should be supplemented with surveys of these others who are visiting the study area because of the event:

- Nonresident producers of the event

- Nonresident sponsors of the event

- Nonresident media representatives covering the event

- Nonresident exhibitors at a trade show and other vendors at the event

Excluding (e.g., time switchers) or including (e.g., retained residents) other categories of individuals who attend the event raises serious issues of validity.

Building on this past research on measuring visitor spending to improve survey and cost-factor model methodologies should move researchers and practitioners away from Crompton et al.'s "best guesses" and toward his accuracy ideal (2001, p. 80) to the benefit of all. 


\section{REFERENCES}

Alexander, L. M. (1953). "The Impact of Tourism on the Economy of Cape Cod, Massachusetts." Economic Geography, 29: 320-26.

Alreck, Pamela, and Robert B. Settle (1995). The Survey Research Handbook. 2nd ed. Homewood, IL: Richard D. Irwin.

Armoogum, J., and J.-L. Madre (2003). "Weighting and Correcting LongDistance Travel Surveys." In Capturing Long-Distance Travel, edited by K. W. Axhausen, J.-L. Madre, J. W. Polak, and P. L. Toint. Baldock, Great Britain: Research Studies Press Ltd, pp. 151-69.

Baretje, R. (1982). "Tourism's External Account and the Balance of Payments." Annals of Tourism Research, 9 (1): 57-67.

Bowen, David (2002). "Research through Participant Observation in Tourism: A Creative Solution to the Measurement of Consumer Satisfaction/Dissatisfaction (CS/D) among Tourists." Journal of Travel Research, 41 (1): 4-14.

Braun, Xander, and White (2002). "The Impact of the Cruise Industry on a Region's Economy: A Case Study of Port Canaveral, Florida." Tourism Economics, 8 (3): 281-88.

Brown, Michele D., Turgut Var, and Seokho Lee (2002). "Messina Hof Wine and Jazz Festival: An Economic Impact Analysis." Tourism Economics 8 (3): 273-79.

Bull, Adrian (1995). The Economics of Travel and Tourism. 2nd ed. South Melbourne, Australia: Longman.

Burd, Martha (1991). "The Economic Impact of Tourism Industries in B.C." Draft, unpublished manuscript, British Columbia Ministry of Development, Trade and Tourism, Canada, September 27.

Bureau of the Census, United States (1979). 1977 Census of Transportation, National Travel Survey, Travel During 1977. Washington, DC: U.S. Government Printing Office.

Bureau of Transportation Statistics (1997). 1995 American Travel Survey Technical Documentation. Washington, DC: U.S. Department of Transportation.

Carlsen, Jack (1995). "Gathering Information: Meetings and Conventions Sector Research in Australia." Journal of Tourism Studies, 6 (2): 21-29.

Cavanagh, Carl, Ruth McDougall, and Martha Burd (1992). British Columbia Tourism GDP, 1981-1991: Methodology. Victoria, BC: British Columbia Ministry of Finance and Corporate Relations.

Chau, Peter (1988). "The Canadian Tourism Economic Impact System." Paper prepared for Tourism Canada, Ottawa, Canada, August 1, 1988.

Chhabra, Deepak, Erin Sills, and Frederick W. Cubbage (2003). "The Significance of Festivals to Rural Economies: Estimating the Economic Effects of Scottish Highland Games in North Carolina." Journal of Travel Research, 41 (May): 421-27.

Church, Donald A. (1969). "A Proposed Model for Estimating and Analyzing Travel Expenditures." Journal of Travel Research, 8 (1): 1-6.

Commission of the European Communities, International Monetary Fund, Organisation for Economic Co-operation and Development, United Nations, and World Bank (1993). System of National Accounts 1993. New York: United Nations.

Crompton, John L. (1999). Measuring the Economic Impact of Visitors to Sports Tournaments and Special Events. Ashburn, VA: National Recreation and Park Association.

Crompton, John L., Seokho Lee, and Thomas J. Shuster (2001). "A Guide for Undertaking Economic Impact Studies: The Springfest Example." Journal of Travel Research, 40 (August): 79-87.

Daniels, Margaret J., William C. Norman, and Mark S. Henry (2004). "Estimating Income Effects of a Sport Tourism Event." Annals of Tourism Research, 31 (1): 180-99.

Davis, Jeffrey Sasha, and Duarte B. Morais (2004). "Factions and Enclaves: Small Towns and Socially Unsustainable Tourism Development." Journal of Travel Research, 43 (1): 3-10.

Dwyer, Larry, Peter Forsyth, and Ray Spurr (2004). "Evaluating Tourism's Economic Effects: New and Old Approaches." Tourism Management, 25: $301-17$.

Fleming, William R., and Lorin Toepper (1990). "Economic Impact Studies: Relating the Positive and Negative Impacts to Tourism Development." Journal of Travel Research, 29 (1): 35-42.

Frechtling, Douglas C. (1974). "A Model for Estimating Travel Expenditures." Journal of Travel Research, 12 (4): 9-12. (1994a). "Assessing the Impacts of Travel and TourismMeasuring Economic Benefits." In Travel, Tourism, and Hospitality Research: A Handbook for Managers and Researchers, 2nd ed., edited by J. R. Brent Ritchie and Charles R. Goeldner. New York: John Wiley \& Sons, pp. 367-91.

- (1994b). "Tourism Economic Impact Models." In Tourism Marketing and Management Handbook, 2nd ed., edited by Stephen F. Witt and Luiz Moutinho. Englewood Cliffs, NJ: Prentice-Hall, pp. 488-96.

(2001). Forecasting Tourism Demand: Methods and Strategies. Oxford, UK: Butterworth-Heinemann.

Gazel, Ricardo C., and R. Keith Schwer (1997). "Beyond Rock and Roll: The Economic Impact of the Grateful Dead on a Local Economy." Journal of Cultural Economics, 21: 41-55.
Getz, Donald (1994). "Event Tourism: Evaluating the Impacts." In Travel, Tourism, and Hospitality Research: A Handbook for Managers and Researchers, 2nd ed., edited by J. R. Brent Ritchie and Charles R. Goeldner. New York: John Wiley \& Sons, pp. 437-50.

Getz, Donald, Martin O'Neill, and Jack Carlsen (2001). "Service Quality Evaluation through Service Mapping." Journal of Travel Research, 39 (4): 380-90.

Haynes, Landon G. (1975). "A Known and Equal Chance.” In Sixth Annual Conference Proceedings. Salt Lake City, UT: The Travel Research Association, pp. 95-97.

International Institute of Tourism Studies (2005). The 29th Annual Marine Corps Marathon Economic Contribution and Characteristics of Visitors and Local Spectators. Washington, DC: George Washington University.

Kasimati, Evangelia 2003. "Economic Aspects and the Summer Olympics: a Review of Related Research." International Journal of Tourism Research, 5: 433-44.

Kim, Dae-Kwan, Daniel M. Spots, and Donald F. Holecek (1998). "A Comparison of Estimates of Statewide Pleasure Trip Volume and Expenditures Derived from Three Household Surveys." In Travel Research Roundup: Branding the Travel Market, 29th Annual Conference Proceedings. Lexington, KY: Travel and Tourism Research Association, pp. 109-19.

Lian, J.-I., and J.-M. Denstadli (2003). "How Reliable Are Household Surveys for the Description of Air Travel?" In Capturing LongDistance Travel, edited by K. W. Axhausen, J.-L. Madre, J. W. Polak, and P. L. Toint. Baldock, Great Britain: Research Studies Press Ltd., pp. 110-19.

Long, Patrick T., and Richard R. Perdue (1990). "The Economic Impact of Rural Festivals and Special Events: Assessing the Spatial Distribution of Expenditures." Journal of Travel Research, 28 (4): 10-14.

Madden, John R. (2002). "The Economic Consequences of the Sydney Olympics: The CREA/Arthur Andersen Study." Current Issues in Tourism, 5 (1), pp. 7-21.

Madre, Jean-Loup, and Joelle Maffre (2001). "Is it Necessary to Collect Data on Daily Mobility and Long-Distance Travel in the Same Survey?" In Personal Travel: The Long and the Short of It, Conference Proceedings June 28-July 1, 1999. Washington, DC: Transportation Research Board, pp. 343-64.

Mak, James, James Moncur, and David Yonamine (1977). "How or How Not to Measure Visitor Expenditure." Journal of Travel Research, $16(1): 1-4$

Manente, M., and V. Minghetti (1998). "The Collection of International Tourism Expenditure Statistics on Open Area: Methodology and Applications. The Case of the Veneto Region." Tourism and Hospitality Management, 4 (1): 93-106.

Mathieson, Alister, and Geoffrey Wall (1982). Tourism: Economic, Physical and Social Impacts. London: Longman.

Matheson, Victor A. (2002). "Upon Further Review: An Examination of Sporting Event Economic Impact Studies.” The Sport Journal, 5 (1): 2.

Meyberg, Arnim H., and Werner Brog (1981). "Validity Problems in Empirical Analyses of Non-Home-Activity Patterns." In Transportation Research Record 807: Travel Demand Forecasting and Data Considerations. Washington, DC: Transportation Research Board, pp. 46-50.

Mihalic, Tanja (2002). "Tourism and Economic Development Issues." In Tourism and Development: Concepts and Issues, edited by Richard Sharpley and David J. Telfer. Clevedon. UK: Channel View Publications, pp. 81-111.

Mules, Trevor (1999). "Estimating the Economic Impact of an Event on a Local Government Area, Region, State or Territory." In Occasional Paper No. 28: Valuing Tourism Methods and Techniques, edited by Kristine Corcoran. Canberra, Australia: Bureau of Tourism Research.

National Task Force on Tourism Data (1989). Final Report. Ottawa: Minister of Supply and Services Canada.

Office of Travel and Tourism Industries (2004). In-Flight Survey of International Air Travelers. Washington, DC: U.S. Department of Commerce.

Ogilvie, F. W. (1933). The Tourist Movement. London: P. S. King

Ortolani, G. G. (2000). "Revision of the Collection Systems for the Travel Item in the Balance of Payments of the European Member States following Stage Three of the European Monetary Union." In Tourism Satellite Account (TSA) Implementation Project: Enzo Paci Papers on Measuring the Economic Significance of Tourism, vol. 1. Madrid, Spain: World Tourism Organization.

Ritchie, J. R. Brent (1975). "Some Critical Aspects of Measurement Theory and Practice in Travel Research." Journal of Travel Research, 14 (1): pp. $1-10$.

Rovelstad, James M. (1994). "Model Building and Simulation.” In Travel, Tourism, and Hospitality Research: A Handbook for Managers and Researchers, edited by J. R. Brent Ritchie and Charles R. Goeldner. New York: John Wiley \& Sons, pp. 503-12.

Ryan, C. (1998). "Economic Impacts of Small Events: Estimates and Determinants-A New Zealand Example." Tourism Economics, 4 (4): $339-52$. 
Rylander, Roy G., Dennis B. Propst, and Terri R. McMurtry (1995). "Nonresponse and Recall Biases in a Survey of Traveler Spending." Journal of Travel Research, 33 (4): pp. 39-45.

Sanders, Thomas B., Sarah J. Beard, David Levesque, and George Smith III (1993). "A New Index for Tourism: The Case of Maine and the Canadian Provinces." Journal of Travel Research, 32 (2): 49-53.

Seaton, A. V. (1997). "Unobtrusive Observational Measures as a Qualitative Extension of Visitor Surveys at Festivals and Events: Mass Observation Revisited." Journal of Travel Research, 35 (4): 25-30.

Sheldon, P. J. (1990). "A Review of Tourism Expenditure Research." In Progress in Tourism, Recreation and Hospitality Management, vol. 2, edited by C. P. Cooper. London: Belhaven Press, pp. 28-49.

- (1993). "Forecasting Tourism: Expenditures versus Arrivals." Journal of Travel Research, 32 (1): 13-20.

Smith, Stephen L. J. (2000). "New Developments in Measuring Tourism as an Area of Economic Activity." In Trends in Outdoor Recreation, Leisure and Tourism, edited by W. C. Gartner and D. W. Lime. New York: CAB International, pp. 225-34.

Stynes, Daniel J., and E. Mahoney (1989). "Measurement and Analysis of Recreational Travel Spending." In Abstracts, 1989 Symposium on Leisure Research. Alexandria, VA: National Recreation and Park Association.

Travel Industry Association of America (2004). Impact of Travel on State Economies, 2004 Edition. Washington, DC: Travel Industry Association of America.

Tribe, John (2005). The Economics of Recreation, Leisure \& Tourism. 3rd ed. Oxford, UK: Elsevier.

Turco, Douglas M. (1994). "Measuring the Net Economic Impact of an International Sporting Event." Visions in Leisure and Business, 12 (4): 26-38.

Tyrrell, Timothy J., and Robert J. Johnston (2001). “A Framework for Assessing Direct Economic Impacts of Tourist Events: Distinguishing
Origins, Destinations, and Causes of Expenditures." Journal of Travel Research, 40 (August): 94-100.

United States Department of Transportation (2005a). Transportation Expressions. Retrieved August 17 from http://www.bts.gov/cgibin/btsprod/expr/expr.pl.

(2005b). 1995 American Travel Survey: An Overview of the Survey Design and Methodology. Retrieved August 23 from http://www. bts.gov/publications/1995_american_travel_survey/an_overview_of_ the_survey_design_and_methodology/index.html.

Vanhove, Norbert (2005). The Economics of Tourism Destinations. Oxford, UK: Elsevier Butterworth-Heinemann.

Vaughan, D. R., H. Farr, and R. W. Slee (2000). "Estimating and Interpreting the Local Economic Benefits of Visitor Spending: An Explanation." Leisure Studies, 19: 95-118.

West Virginia University (1981). Creating Economic Growth and Jobs through Travel and Tourism. Washington, DC: U.S. Government Printing Office.

World Tourism Organization (2000). Measuring Total Tourism Demand Madrid, Spain: World Tourism Organization.

(2005a). Basic References on Tourism Statistics. World Tourism Organization. Retrieved August 16, 2005, from http://www.worldtourism.org/statistics/tsa_project/basic_references/index-en.htm. (2005b). "System of Tourism Statistics (STS) and its Links with the General Statistical System." Retrieved August 18, 2005, from http://www.world-tourism.org/frameset/frame statistics.html. (2005c). Measuring Domestic Tourism and the Use of Household Surveys: A Working Paper, (v. 1), May 2005. Madrid, Spain: WTO Department of Statistics and Economic Measurement of Tourism.

Youssefzadeh, M. (2003). "Long-Distance Diaries Today: Review and Critique." In Capturing Long-Distance Travel, edited by K. W. Axhausen, J.-L. Madre, J. W. Polak, and P. L. Toint. Baldock, Great Britain: Research Studies Press Ltd., pp. 28-43. 